\title{
Remembrance and Identity in Constructing the Narration of the Individual and the Community
}

\begin{abstract}
In the article, I present two currently co-functioning diagnoses of Polish modernity. One is separatist, emphasizing the division, without hope of consent - a vision of two conflicted tribes, differing in their attitude to the past and history. The second vision assumes the possibility of communication, pointing to the relational character of the current conflict, which is based on the need for recognition. Remembrance is not a dividing instrument here, but a common good and value, and the chance for communication is the relationship of recognition.
\end{abstract}

Keywords: narration of the community, narration of the individual, identity, recognition, refusal of recognition, contempt.

\section{Pamięć i tożsamość w konstruowaniu narracji jednostki oraz wspólnoty}

\begin{abstract}
Abstrakt
W artykule przedstawię dwie funkcjonujące dzisiaj obok siebie diagnozy polskiej współczesności. Jedna to separatystyczna, podkreślająca rozłam, bez nadziei na zgodę wizja dwóch odmiennych, zwaśnionych plemion, różniących się stosunkiem do przeszłości i historii. Historia i pamięć są tutaj kryterium podziału. Druga wizja zakłada możliwość porozumienia się, wskazując na relacyjny, oparty na potrzebie uznania charakter obecnego konfliktu. Pamięć nie jest tutaj narzędziem podziału, ale dobrem i wartością wspólną, a szansą na porozumienie się są relacje uznania.
\end{abstract}

Słowa kluczowe: narracja wspólnoty, narracja jednostki, tożsamość, uznanie, odmowa uznania, pogarda.

* University of Opole, Institute of Pedagogical Sciences. 


\section{Introduction}

The starting point for the discussion in this work is the question of the narration of the Polish community. The notion of "the narration of the community" is based on the concept of Alisdair MacIntyre (1996) presented in the book entitled After Virtue. In that book, the author shows a relationship between an individual identity, which is always a narration (a story, a history of "me"), and a collective identity (which is always also revised in the form of a story about a nation). The second very important conclusion resulting from MacIntyre's theory is the indication of a precedence of the individual identity (history of "me") over the identity of the community (our history about "us"). I think that the causes of what we experience today, and what I call a broken or divided community, may be sought in the fact that there is no single moral tradition from which the narration of our community has originated, and which may be shared by us all. The moral tradition on which the narration of the community is based is another important notion from MacIntyre's theory.

The question about the Polish moral tradition which has formed our community identity and which, as a consequence, decides about our individual identity today; the question about whether it is a single tradition or there are many of them; the question about relationships between those traditions (does any of them dominate and are the others forgotten or supplanted?) seems a promising direction to follow in order to understand what has happened to our country. It is an important question for pedagogy and pedagogists. It is an important question for theoreticians and practitioners of education. How can one introduce an individual to culture (one of the widest definitions of education defines that process in that way) if it there is no clear belief and consent as to the origins, the sources of our feeling of community? If one tradition on which a community is based takes a dominant position and the other tradition, which is also important, is supplanted, rejected, and forgotten, which values, from where derived, and in which axiological and normative order arranged, may form that "world" for education, which we introduce an individual to?

Nowadays, we use diametrically opposed manners to describe many historical events. Those descriptions concern the near and the distant past. For some, the Round Table was the beginning of important democratic transformations and contributed to the fall of communism in Eastern Europe; for others, it was a national betrayal. For some, our Polish-Jewish relationships are difficult, not obvious, full of both heroism and shame based on guilt. For others, they are obvious, only admirable, based on sacrifice, help, and support. Our past, our attitude to the events of which the past consists is described by two different narrations today. Therefore, questions arise which this work tries to answer: whether we are still a single community or have we already become permanently divided, and do we look at each other like aliens, conflicted, or even hostile tribes despite the territory, 
language, and tradition we share? And what role does our shared remembrance play here? Is it single and dominating or are there various types of remembrance of our past which are in conflict with each other?

I shall try to answer those questions here although it is very difficult and complex and there is a great risk of trivialization or common simplifications. To do this, I shall try to present a manner of understanding the notion of the narration of the community derived from the theory of virtues of MacIntyre (1996), the relationship of that category with the process of constructing the identity of the community and the identity of the individual, and moral traditions described by it, ones on which the narration of the community and the narration of the individual are (or may be) based. Using those categories, I attempt to reconstruct the two different moral traditions which the modern Polish narration of the community is based on. These are: the forgotten tradition of Slavs, which is treated with great caution, and the dominating and generally accepted Christian-national-messianic tradition.

In this work, I ask whether the break in the narration of our community which can be observed today may be a consequence of that original and, somehow, fundamental duality. In the conclusions, I propose a relationship of recognition as a manner of solving that social crisis by referring to two discursive events, which are characteristic or even representative of our broken community. The pedagogy of recognition could become a way to overcome the conflict which has divided the country in a manner which has been unprecedented up to date. The education of recognition, an upbringing in a pedagogical culture of recognition, seems to be that type of social practice which could help the community to end the crisis and to overcome the conflict between two narrations of our community which exist today.

This work uses the methodology of qualitative research. It is based on a critical analysis of MacIntyre's works concerning categories such as the narration of the community, the narration of the individual, and the moral tradition which the narration of the community is based on. Moreover, I refer to works by Maria Janion (2007) concerning co-existing moral traditions of the Polish community which are in dispute over domination or hegemony, i.e. Slavs and Christians, and works by Axel Honneth (2012) about the relationship of recognition, fight for recognition, and refusal of recognition. In addition, I use the description and interpretation of modern discursive events illustrating the two narrations of our broken (Polish) community.

\section{Community sources of narrative identity}

The question of "who I am" is one of the most fundamental questions asked by an individual today. The reality we live in is becoming so complex that it is not a consistent or safe point of reference at all. We have to find such points of reference over and over again or we must construct them over and over again. Today, our 
individual identity is a task to be completed, our biographic problem, or even a challenge. It is flexible, changeable; at the same time it is complex and noncontinuous. To be able to get the feeling of consistency which is so important for us, we have to use various ways of uniting the identity which is being constantly deconstructed or modified. With constant changeability, a modern individual aspires to a certain permanency, to the feeling of security based on a conviction that they know the answer to that one fundamental question and that the answer does not change. That question is: who am I? and it concerns identity. It is the narrative practices based on the permanently maintained history about "me" that are of such a unifying nature.

Each of us is immersed in a certain story about the world. That story has a cognitive, affective, evaluative, temporal, and interpretative dimension. A cognitive one, as it contains explanations of all events we participate in and of decisions we make. An affective one, as it forms bases for experiencing them emotionally and defines our emotions. An evaluative one, as it enables us to assess our own behaviours and those of other people based on the system of norms and rules contained in it. A temporal one, as it is always constructed on a certain remembrance of the past, a certain representation of the present, and a certain vision of the future. An interpretative one, as owing to that story we are able to find our way through a sphere of meanings which are brought each day, in each situation, by our relationship with others, our interactions, and situations we participate in. That story about the world helps us to understand what is happening around us, what is happening with us, and what is happening in our relationships with others.

\section{That story about the world is a narration}

As Jacek Wasilewski writes (2012: 21),

An individual is set in a narrative paradigm. Narrations are treated as symbolic acts (words or actions, e.g. dance) with a specific order and meaning for those who experience, create, or interpret them: a narration is a conceptual framework for understanding people's decisions, conversations, and actions. A narration, being a system which contains points of reference, lends a meaning to messages. We have to share it to grasp that meaning.

I tell my story which, despite the changing conditions of my life and various situations and circumstances, is based on the same foundations, i.e. family stories, socialization patterns, values passed by "significant others", or the everyday social practices I participate in. The narrative identity is an ability to maintain the same history about "me" despite changing conditions. But my story, that narration maintained by me, comes from somewhere and has its source somewhere. It is the narration of the community that is its source. 
The notion of the narration of the community I use in my research and my analyses comes from works by MacIntyre. What is particularly inspiring for me is his work titled After Virtue (1996). When writing about the narration of the community, he observes that throughout history several very clear moral traditions may be distinguished, presented always in the form of stories (narrations), which determined the place of an individual in a society, the individual's position, a set of available types of behaviour, and values which became goals of the individual's accepted and desired actions. MacIntyre believes that it is possible to reconstruct moral traditions present over centuries which form the narration of a specific community. It is the narration of the community that is the genesis of our actions, our relationships with others, the ways we assess ourselves and others, our goals, and our aspirations; it is a narration of the community, which consists of stories about our past passed from generation to generation, or our family stories supported and somehow confirmed with symbolic souvenirs, that helps us to answer the question: who am I?

We cannot escape the narration of our community. It contains both the glorious and the dishonourable past; it also carries stories about sanctions waiting for those who violate rules and norms accepted by the community. The narration of our community is our compass; it is, following a reference to a metaphor created by Zygmunt Bauman (2003), a certain lighthouse which prevents us from getting lost or even from drowning in the ocean of non-transparent, risky, and often misunderstood reality. The remembrance of the past, the remembrance of symbols, and the remembrance of customs and traditions (both the material and nonmaterial) form the narration of our community.

MacIntyre (1996) describes certain social practices which form moral traditions constructing the remembrance of the community. I shall try to introduce the category of the narration of the community by demonstrating the moral traditions described by that author, ones which our culture is based on. MacIntyre points to certain shared traditions in which the modern moral discourse is deeply rooted. Those traditions are based on several elements he describes.

The first of them is the model of the Greek heroic society (MacIntyre 1996: 229-241), which may be characterised, most of all, with the fact that the fundamental values of the society and the place of an individual in that society are pre-determined; the individual's obligations and privileges, on the other hand, result from the individual's status. Each person has a specific role in such a society and a status closely related to that role; they are a part of a well-defined and predetermined system of social roles and positions. Therefore, all that an individual does, how they act, what they want, what befits them and their position, and what is unbecoming of them is determined in detail. In such societies, an individual is strictly what they do. It is possible to judge a person only by judging their actions. The virtues of each individual are demonstrated in their actions and their actions, in turn, are always suited to the role assigned to the individual. Life determined in 
that manner is always a story. Therefore, it is an epic or a poetic narration. The moral structure which is a part of that moral tradition and which is characteristic of it contains three important and interrelated elements. Firstly, it is a concept of what the social role assigned to the individual requires from the individual. Secondly, it is the accepted and shared concept of ideals (virtues) which are treated as conditions enabling an individual to fulfil their assigned role. Thirdly, it is a concept of the human condition, which is, in that tradition, treated as frail and subject to destiny and death, which are indisputable determinants of human life. All those three elements of the moral structure of society depend on each other and form a single whole. They become understandable for individuals owing to their narrative structure. The narration of a specific community is fulfilled (or present) in a collective social structure which forms the moral tradition of that community. In the case of the described tradition of the heroic society "its structure is, in fact, an epic narration played out in reality" (ibidem: 241).

The second tradition described by MacIntyre is a tradition originating from the works of Sophocles. Here, the final instance an individual appeals to is a certain god and his verdict. A human judgment of a certain situation does not have to be consistent with the divine judgement; however, the divine verdict ends a dispute, although it does not settle it. Such a verdict and such an instance are part of that tradition because a situation of an individual is already described in it not only by a specific and assigned role, but also by the possibility of going beyond that role. That tradition refers to the narration as it notices that human life takes, in its nature, a form of a dramatic narration. However, what appears in that narration is an individual, the individual's actions and characteristics, possibilities, conditions (virtues) disclosed in the individual's actions and, on the other hand, a community with its needs, its interests, and its continuation. In the tradition originating from dramas by Sophocles, a community becomes, like an individual, a character in that drama, one having its own narration. Therefore, you may read that tradition not only from the angle of individual narrations of people, aspiring to perfection or objecting to roles they have been assigned. It may also be read as a narration of a certain community, the narration speaking about the community's needs, expectations, and duties, which an individual must/wants to/may fulfil. In that tradition, there is also a very important issue related to going beyond the roles assigned to an individual. An individual may yield to the roles they have been assigned or oppose and reject them. They may also win or suffer a moral defeat. Therefore, that tradition contains an assumption that there exists a certain moral order which requires certain behaviours from individuals and rejects, and stigmatizes other behaviours or even punishes them. Thus, a belief arises about the existence of a certain order verifying our actions and lending a true or false status to them.

The third tradition originates from Aristotle's philosophy and is presented by MacIntyre in an extremely critical and arguable manner. That tradition is based on a belief that each action or practice strives to a certain good. The notion of good is 
intertwined here with the notion of the purpose of human activity. Statements on what is good and what is just are factual; they are natural for a human and they are a part of human nature. In their nature, people strive towards specific goals, towards good. Good is a condition where an individual acts well, is in a good condition where they approve of themselves, and remains at peace with the divine. Virtues are traits which enable an individual to strive for good and to achieve it. "A direct result of behaving in line with the requirements of virtue is a choice demonstrating itself in a just action: the virtue is a reason for the fairness of the purpose we choose" (ibidem: 273). That tradition points to moral education. Because what does it mean to act virtuously? Such behaviour is based on inclinations formed by exercising virtues.

An educated subject of moral education must, obviously, know what they are doing when they make judgements or act virtuously. Therefore, they do what is virtuous because it is virtuous. That fact makes an action according to the requirements of virtues different from an action in line with certain properties which are not virtues, but only appear virtuous" (ibidem: 274).

The essence of such an understanding of good would lie in the skill of differentiating between what individuals believe is good for them in specific conditions, a specific situation, and specific time, and what is really good for them. The essence of noticing a relationship between good and morality, characteristic of that tradition, would be to ask a question about the conditions which must be met in the era concerned to build a community following a shared project, a community which would realize a certain shared good recognized as such by all individuals following the project. A community requires two types of agreements; it must agree on an opinion concerning the nature and significance of virtues and on an opinion about the consequences of individual offences and abuses. Therefore, that tradition asks a question both about virtues and about offences, treating the former as a condition of success and development and the latter as obstacles or barriers.

The belief of Aristotle that, regardless of differences in our opinions during each action, we are able to reach an agreement as to what a virtue and what an offence is, has become a starting point for disputes and criticism being part of that tradition. Apart from many threads of those disputes, what seems important is a failure to recognize the great developmental role of conflict based on an inability to reach a rational agreement concerning the issue of offences and virtues (to use the same terminology).

Another tradition which MacIntyre's theory of virtue comes from is the medieval tradition. That tradition is based on the belief that social life is formed according to a perfect outlook on the world, which reflects the universal order. There is no element of social life which does not have its place in the universal order of things. That order may be endangered by the circumstances of real life and, therefore, that tradition emphasizes mainly the importance of virtues such as patience and purity. 
Purity is fundamental as the medieval world is accompanied with awareness of how easily the understanding of the highest good may be disturbed by the external world; patience is also very important as it is a virtue of lasting in the face of evil (ibidem: 321).

Passing over the issue of the dispute between the theory MacIntyre reconstructed here and the philosophy of St. Thomas (which concerns, most of all, the issue of the unity of virtues continued by St. Thomas according to Aristotle's philosophy), it is worth noticing that, in MacIntyre's opinion, the medieval tradition contributed a lot to the development of both moral theory and practice (cf. Dziemianowicz 2016: 47-50).

The moral traditions described above show how much our individual identity is rooted in the narration of our community. And how important, for our identity, the moral tradition is, one which that community narration is based on. They show that what is assigned to my role, my life condition, my situation, what is available to me as a certain accepted range of behaviours suitable to that situation is not constructed by me each time. Ways of behaving which I prefer, my choices, my judgements, the ways I show emotions, and my relationships with others are based on what I inherit. I inherit them, I take them from past models, from the behaviours of my relations, my educators; from values and the heritage of my community. I inherit obligations being part of the tradition of my community; I inherit its traumas and humiliations. A part of the narration of my community, which forms my identity, contains events which I can be proud of as well as those which may be a reason for shame and embarrassment. I cannot escape from the narration of my community; I cannot reject it. Even if I negate some of its fragments, if I reject or deny them, they still play a great role in the history of "me" constructed by me. Remembrance is of great importance here. Shared social remembrance guarantees that we are able to communicate. Without it we lose points of reference both in what our agreement pertains to and in what we are in dispute about.

That being so, can we imagine today such a synthetic presentation of the narration of our community? Would it be a single narration or two narrations? If there are two different narrations already, maybe they are accompanied by a single moral tradition at least? A tradition which is a foundation of the narration of our community?

\section{Two narrations of our community}

The first question that comes to mind at this moment is whether the narration of the modern, Polish community is based on a single moral tradition. That issue is related to another, no less important question: why does it require our attention, why it is today that we focus attention on the issue of moral tradition which the narration of our community comes from? 
This is what Tadeusz Sucharski, who examines the matter, writes about it:

The effort of defining the Polish identity anew becomes particularly necessary in the era of "the formation of the Polish nation", although certainly the form emphasizing the continuation of that process and its imperfection would be more correct. Maria Janion underlines that she is writing a book and making an effort at reflexion about the Polish identity in the period when Polish people, particularly young ones, feel the condition of "suspension, disinheritance, exclusion", which results not only in "declarations of saying goodbye to Poland" but also actual emigration from their country. Her book is somehow a confessional and a distorting mirror of modern Poland and, at the same time, it makes us realize our dramatic dilemma as well as the inadequacy and insufficiency of the tradition which sustained us for two centuries. It is a confessional, as it listens to Polish "sins" which are ruthlessly disclosed by modern culture contesting "the Romantic neurosis". It is a distorting mirror because it exposes nation-centric enslavement in a trivialized messianic and martyrological stereotype. But it also warns against the manipulative inclinations of politicians and columnists, who use those clichés eagerly and cynically and consolidate the spreading xenophobic and national-Catholic attitudes, the deplorable modern condition of mentality of the "chosen nation" (Sucharski 2008: 226).

These words refer to the book by Janion titled Niesamowita słowiańszczyzna (2007), where the author points to several different traditions which are often antagonistic to each other and which are used today by us, modern researchers, modern Polish people.

One of them is, certainly, the national and martyrological tradition. Often trivialized and simplified, it is based on certain national myths and symbols, which are present in the area of our shared imagination. Deeply rooted in the Christian culture, it is certainly of a masculine gender. Its foundations are formed by relationships of male brotherhood and friendship.

Perfect models of relationships of that type include noble masters-brothers or knight regiments in the old Polish culture as well as Philomaths' and Philarets' half-secret associations in modern culture; 19th-century conspirators fighting for the independence of their motherland; participants in numerous 20thcentury youth movements, many of whom chose Philomats as their patrons; and Piłsudski's legionaries. They make a picture of a string of generations which pass the ideal model of a fighting male community forward. It is dominated by patriotism, with brotherhood as the highest value, brotherhood established and maintained during various collective actions taken for public, military, social, or touristic purposes. Those include hunts, hikes and trips, associations, corporations and clubs, fights and battles. In Poland, it was the national cavalry, Hussars and lancers, beautiful like in a painted picture, to be looked at and admired, that were particularly adored (Janion 2007: 267-268). 
That male community is based on two foundations or social roles. These are two male aspirations; one oriented at the accomplishment of goals specified by a family and the other one at the accomplishment of goals specified by the male community. That second aspiration was related to the so-called "sociological creativity" and was very important for the formation of the modern notion of the nation.

Passionate, male brotherhood was supposed to play a significant constitutive role in that process. Family, on the other hand, is treated in that tradition as a less important area, as it only ensures survival of the species. Orientation to the nation as a "male thing", as an area related to male bravery, ruthlessness, and brotherhood, is close to nationalism, which had great foundations for being born and developing in that tradition.

A modern understanding of a nation and the nationalism, which came into being together with it, were related to the stereotype of masculinity which contained properties of male identity presented adequately. The mythology of a male community, a ruthless fight, and war rage has always played a particularly important role here (ibidem: 270).

By describing that moral tradition in greater detail, the tradition from where one of today's narrations of our community has certainly originated, the quoted author shows that the religious and cultural division started thousands of years ago and lies between the Latin West and the Greek East. Maria Janion calls that mentality (a narration of the community if we use MacIntyre's language) a post-colonial mentality. Having been colonized many times, we are continuously striving to find someone that we could subdue and colonize. Enslaved in those opposing aspirations as well as shared and maintained social emotions (of domination and being subdued), today we have a problem with the narrative foundations of our functioning.

The second narration of our community is the culture of Slavs, which is described increasingly often. As a result of the specific course of the Christianization of Poland, which involved a particular attitude of Latin missionaries towards Slavic mythology and religion, they were somehow deleted from and forgotten in our tradition. "Christian missionaries and medieval chroniclers lacked deep inquisitiveness, interest, and desire to look into spiritual life of people they happened to convert" (Szyjewski 2003: 9). This is where a peculiar oblivion or even contempt of the Slavic culture, which is very often called "primitive", comes from. Historians dealing with the issue discussed here (ref. to Łowmiański 1979; Strzelczyk 2002; Modzelewski 2004; Skrok 2006) describe various historical traumas related to the destruction of traces of Slavic religion, Slavic cults, and Slavic culture. Their works speak about the defeat of the Slavs, about the loss of their own mythology and their own memory resulting from joining the Latin civilization.

Writing those words, I am, of course, aware of the fact that in the opinion of historians "we have to remember that if the Polish state had not been included in 
the Christian monarchy of Europe, today we would experience the fate of modern small ethnical minorities, mainly people of Lusatia crushed by the Germans, who are called the only witness of the land of Polabian Slavs alive today" (Strzelczyk 2002: 80). Historic disputes and deep arguments are not my purpose in this work. Here, I show two traditions present in the humanities, where our community comes from. I show them, searching for an answer to the question: what has happened with our community today? And in history, I find a certain trace, a starting point for a reflexion on our past, that very distant one as well. Has that break been inherited over the ages, that opposition, or even that antagonism, which grows stronger the more efficiently and effectively one of the traditions described here dominates the other, using practices of displacement, denial, refusal of right to exist, even contempt? Is our national remembrance leading us back to Mieszko I and his Baptism, treated as the beginning of Polish identity, sufficient for us all? Is there anyone that wants to, needs to, go back a bit further?

There are various connections with the past before the 10th century. Maybe, following certain Romantics, we should suppose that many Slavic tribes were «badly baptised» and forcefully torn away from their former culture. It is there that we should seek important reasons for that certain break, that certain humiliation, that certain deficiency felt over the ages (Janion 2007: 15).

Does that diagnosis bring us closer to understanding what has happened to our country? Do the two traditions of our community described above enable us to find ourselves in them to an extent that allows us to construct our own identity in an autonomous and safe way? Does the domination of martyrological and messianic national narration enable those who seek deeper and further, seek somewhere else (even in the Slavic culture) to co-exist? To construct an equally worthy Polish tradition? Can both those groups practise traditions important for them in the same safe manner, full of dignity?

After all, today we can observe the phenomenon of a new spirituality related to the wide transformations of religiousness which are taking place in the civilization and culture of the West. This phenomenon is described by, among others, Thomas Luckmann (2011) in his book entitled The Invisible Religion. The author describes new forms of religious practices, small religious communities which look for different forms of participation in a religious life. References based on the remembrance of the ancient Slavic culture (treated antagonistically to the dominating national and messianic tradition) were supposed to have been forgotten and deleted from our past. But, as Aleksander Gieysztor writes,

Linguistic facts themselves speak against seeing it as poor and primitive. It is our sources, in particular written ones, that are fragmentary; however, what may be compared with the surrounding Indo-European world based on those sources, shows a well-formed religious outlook on life, with an outline of 
a higher mythology, with a reflexion on the beyond, with a swarm of ghosts and demons, with magic (Gieysztor 1982: 258).

Seeking an answer to the question of who we are in the past, in remembrance, in Slavic culture is sometimes called construction of an identity based on a myth. Alina Witkowska (1969) describes Zorian Dołęga Chodakowski, one of the main precursors of research on the Slavic world, and writes that in the opinion of that researcher the Slavic world seems to fall entirely into the category of myth.

While conducting pioneering research on names of places and people, on symbols of folk songs and expressions, on rites and beliefs, he always did it with a hope to decipher, as a result, the hieroglyphs of a secret book of Slavic wisdom, undecipherable for people contaminated with civilization, blind and deaf to the voices of past centuries (...). Deciphering blurred signs of a secret book of earth may not be a purely rationalized effort, as there is an element of metaphysical thinking in the notion of a cypher or a hieroglyph itself, thinking which presupposes a possibility of other, non-rational ways of reaching the truth, the essence of things. In this case, that essence of things, reminiscent of the notion of the absolute in Romantic philosophy, was formed by the Slavic sacrum which contained not only the secret riddle of the Slavs but, perhaps, a riddle of life in general, and certainly a riddle of life of a nation (Witkowska 1969: 21-21).

That Slavic myth is, undoubtedly, one of the traditions on which the narration of our community is constructed. In our collective awareness, it competes with the martyrological-Christian tradition. It is also a myth. A myth, according to Jerome Bruner, is

a demonstration of mental life in general. Myths are aesthetic means used to transform the imagined world of primeval forces into accepted objective facts of life in a manner satisfying the need for the conscious and the unconscious. As a result, a myth brings order to the identification of an individual; it enables the individual to crystallize their experiences (e.g. fears) in the narration and share them, as that which is external is easier to name, share and, in the course of the narration, control. That is how a model of scenarios shared by society is created with specific values accepted by the community concerned: in that way a myth performs a pedagogical function (Bruner 1960: 276).

Can it not be that the fight with the Slavic past lasting over centuries, a certain accompanying oblivion strengthened by the dominating narration, has failed to form a certain narrative practice based on mechanisms of displacement, forgetting, and domination? Can it not be that a permanent antagonism and mutual refusal of recognition, being part of our history, has been formed as a model of our shared existence? Will we find an answer to that question in individual narrations and narrations of the community which they are based on? 


\section{Refusal of recognition as a source of a community crisis vs. pedagogy of recognition}

Are we a broken community? Do we form two different communities even today, ones sharing a single language and single geographic territory? And what has happened that we differ so much in such fundamental issues?

I believe that several reasons for that may be given. Firstly, the transformation of 1989 started changes which brought many of us to a loss of economic and symbolic capital. Typically, the phenomenon of anomy appeared, described by sociology and characteristic of a sudden social change: old rules, principles, recognized norms, and symbols stopped working and performing their regulatory role. They went into oblivion, as they were associated with the rejected past. New rules and values had not yet appeared. New strategies of action and accompanying justifications, suited to the transformation, had not yet appeared either. There were no axiological or normative signposts or guides. All people, regardless of their status or social role, were lost and disorientated to the same extent. Some of them somehow managed to pull themselves together in the new situation, understood the market game rules, and started to meet expectations towards them; others failed. They could not do that, they were afraid, they needed more time, or maybe they needed education and support?

Those phenomena were accompanied by a crisis of culture, which has lasted until today. In their book titled Nowe praktyki kulturowe Polaków, Tomasz Szlendak and Krzysztof Olechnicki (2018) show that today no division into high and low culture exists. Everything becomes an event and is ruled by market principles concerning supply and demand. The media revolution brought the domination of pop-culture; globalization levelled out our aesthetic needs, our tastes and preferences. Here, the words of Barbara Skarga (2006) are interesting: she writes that "The intelligentsia has gone quiet". And that silence has become a reason for the lasting existence of the social anomy, which should have been a transitional state rather than a lasting axiological and normative emptiness.

Another reason for the crisis of our community may be mass communication as a dominating form of Polish culture. Banality, truism, and repeated easy and digestible pseudo-thoughts and pseudo-reflexions have become the essence of that mass communication. Today, everything must be nice; no effort has to be made. Film, theatre, literature, or even science should be accessible, understandable, light, and pleasant. Otherwise, they will lose against advertising and pop-culture. Trivialization and superficiality leading to intellectual laziness, dividing the world into ours and that foreign one, an irrational belief that everything that surrounds us is easy, simple, and for immediate consumption, are problems of the present times. Deep analyses, thoroughness, and related prudence in making judgements are not characteristics of our times, our debates, or our communication anymore. The 
cultural universe which enabled us to use symbols and understand each other is slowly disappearing.

Can we do anything with the broken narration of our community? As always, as everywhere, I can see opportunities in education.

In the literature of the social sciences and humanities concerning identity issues, a notion of narrative uniting practices has appeared which, in such difficult and critical times, could become a certain solution to the problem of a broken narration. Relationships of recognition could be such a uniting practice. Pedagogy of recognition could become their carrier. We build relationships of recognition with other people when we give them respect, notice their individual personal value, recognize that they have a moral ability to make decisions (the right to decide about themselves, their position, their choices), respect their contribution in collective efforts, and appreciate their work for the community, regardless of its type and status. Always intersubjective and realized in a relationship with another individual, recognition is built in three areas: family, law, and economy, i.e. the market. Those three areas of recognition enable us to build respect for ourselves, a feeling of security, self-esteem, and a feeling of autonomy. A deficit of recognition is a stimulus to fight for recognition. A refusal of recognition leads to an experience of contempt.

It think that today we experience a great deficit of recognition as a community. I believe that one of the reasons for that deficit may be that broken narration of our community I have described above, which is inconsistent, as it is based on two competitive moral traditions. Therefore, we are constantly fighting with each other and enter into continuous and aggressive disputes. We also meet with a refusal of recognition. As a result, we experience contempt and that experience becomes a critical event, a trauma which may be demonstrated with destructive behaviour of various forms and intensity.

To illustrate a refusal of recognition which was an experience of contempt for those who were affected by it, I am going to describe two discursive events (Kwaśnica 2015). The first of them concerns a refusal of recognition. A refusal of recognition makes us feel scorned. There is nothing worse than an experience of contempt. That is why today people acting from greed (shared by all) not only choose those who would promise them something; they also need those who would ensure recognition for them and take revenge on their behalf for contempt and refusal of that recognition.

I remember that in 2005 , for the $25^{\text {th }}$ anniversary of Solidarność, outstanding Polish film directors were asked to make short film studies about what that transformation had been about, as part of a project directed by Andrzej Wajda entitled "Solidarność, Solidarność". Those short stories were combined into a single film. The opinions of filmmakers concerning the essence of the Polish transformation were very different. In my opinion, one of those short films (directed by Janusz Machulski, "Sushi") helps to understand what has happened today. We can see 
a beautiful, modern office building. People are coming out of it - successful, young, beautiful, rich, and educated. They are going to lunch (lunch rather than the traditional dinner). Next to their office, there is a modern restaurant, as beautiful as they are. They are going in and sitting down; they are silent. A waiter comes up to them and asks them what they would like to eat. They answer in unison, "Three times sushi". And that is the end of the film. That is all. "Three times sushi" is the essence of the transformation for that filmmaker, that director. That discursive event tells us about those who have made it. That image of success lives in our community imagination today. Unfortunately, it is exclusive; it contains a lot of contempt because so many of us do not fit that image ...

And the second event. About regaining recognition. For half a year each year, we live in a small village near Wroclaw. There are mostly small villages around. It is not even a municipality, but a rural commune. Each year, we go to a harvest festival. We also went there after the Law and Justice Party had come to power. It was different. Different from before. All the neighbouring villages had their tables, their stalls. On and by those tables, proud people and their worlds: blood sausages (not for dogs), liver sausages, fruit liqueurs (rather than Chilean wines), home-made goods. People proud, joyful, feeling at home again. Not ashamed of who they were. Not "Januszes" (as mainstream journalists call them) running on a beach in white socks. People like us. Worthy of recognition. I believe that is why they want Law and Justice. That is why they wanted Trump. That is why they want populists. They probably do not believe them more than they believe other politicians. But they have regained their dignity and recognition. And as long as politicians fail to understand that, as editor Lis fails to understand that and writes about "Januszes" and the "500+" child benefit programme with a contempt characteristic of those who have a better life, nothing will change and the devolution will last.

I think that it has affected and it still affects most of us, the so-called "elite". I believe that we have exceeded the acceptable levels of cynicism, hypocrisy, and egoism. We wanted to make a model using our lives and our choices, regardless of the level of our involvement. We have failed. The masses feel great. The masses have told us something important. But can we/do we want to hear it?

Today, we read about a "devolution" of a mass individual. I think that so far we have treated the rebellion of the masses, as understood by José Ortega y Gasset (2006), theoretically or imaginatively. We have believed that emancipation would be possible, among other things, by and owing to education, and that the masses will become... us? We have assumed it was worth becoming involved in helping, in fighting with inequalities not only for noble reasons, but also (from the perspective of our position, our life) to make those who have become emancipated, who have advanced socially similar to us. By writing "we", I think about privileged, involved, and educated people who care about the future of the world and who have somehow succeeded, i.e. intellectuals etc. And it turns out now that the masses are actually rebelling. But they do not want to be us at all. One of the signs of that 
rebellion is the election of each populist who would promise and give something. But people ruling us today give not only money, but also recognition. And the masses were deprived of that.

Therefore, a pedagogy of recognition must be a starting point today. Pedagogy describing the world in a manner which would open people to differences, to diversity, to a dialogue, to another person. Which would not monopolize thinking and deciding. Which would teach argumentation and critical thinking leading to resistance and emancipation. It is only in education based on a pedagogy of recognition that I see an opportunity for a really good transformation.

What is and what may a pedagogy of recognition be? I believe that it may be a great alternative, a certain counterbalance to the pedagogy of shame present in the public sphere. Pedagogy of recognition refers to the category being developed at present by Axel Honneth (2012), which points out that recognition treated as an intersubjective value, as a basis for our social relationships with others, is a condition and the possibility of working on one's own identity today. Recognition given to us by others helps us to have a positive attitude to ourselves, self-esteem, selfrespect, a generalized feeling of security which is called ontological, the awareness of one's rights, the ability to exercise them; it helps us to participate, to feel solidarity with others, and to feel useful based on an affiliation to a specific community. A deficit of recognition is treated by researchers dealing with those issues, e.g. Honneth (2012) or Hannah Arendt (2008), as a reason for moral and social conflicts and crises. A self-respect (Selbstachtung) is a foundation for an individual; institutions must "find their foundation in practices and order of recognition realized intersubjectively" (Honneth 2012: XLV). Honneth repeats that the greatest blow which may be experienced by an individual is a loss of self-respect, which is a result of a refusal of respect by people from whom respect is expected. The description of the lamentable situation of refugees, whose fate is discussed by Arendt (2008) in Korzenie totalitaryzmu, is reflected in Honneth's considerations. Their misery does not consist in the fact that

they are deprived of the right to freedom, aspiration to happiness, or equality in law and freedom of opinion, as those formulas have been developed to solve problems within specific communities, but in the fact that they do not belong to any community at all. The damage they suffer is not the fact that they are not equal in law, but the fact that there is no law for them; not the fact that they are persecuted, but the fact that no one even wants to persecute them (Arendt 2008: 413).

As Olga Ciemielęcka writes (2014: 158),

A negative experience which is a demonstration of a refusal of recognition, an experience of contempt, injustice, no respect, or being ignored is, in Honneth's opinion, a moral harm to an individual. Society is understood as an interper- 
sonal space where «an exchange of recognition» takes place through everyday practices of showing respect to others, which are, in turn, a basis for gaining recognition by an individual.

A deficit of recognition leads to a fight for recognition; a refusal of recognition results in an experience of contempt. I believe that the modern Polish reality is an experience of contempt shared by a great part of our society. We show our contempt (refusal of recognition) to each otherness, each distinctness. That may be social, axiological, or economic otherness or otherness of a lifestyle and life quality. Out of those, religious and cultural otherness give rise to the most conflicts. Closed to distinctness, intolerant to differences, we are becoming a community based on fear, a community oriented at protecting its own interests, beliefs, and values. Pedagogy, as no other scientific discipline, and education, as no other social practice, may overcome that tendency, may support that openness and dialogue (one "with no arbiter" as well), teach behaviour based on aspiration to understand the difference rather than reduce it. Relationships of recognition are built in three different areas: in the sphere of a family (relationships of security based on fundamental trust), in the sphere of law (relationships based on an autonomous ability to formulate moral judgements, to make choices, to have, adopt, and observe law), and in the sphere of economy (relationships based on loyal usefulness of each of us, a feeling of usefulness based on our possibilities rather than expectations formed for us). Pedagogy of recognition has the following tasks in that area:

1. To diagnose manners of building relationships of recognition in those three spheres;

2. To describe and disseminate all obstacles, difficulties, and deprivations in relationships of recognition in those three spheres;

3. To initiate, design, and animate actions with the aim of overcoming those obstacles and difficulties;

4. To build a culture of recognition - respect for the other individual, both in relationships between individuals and in institutions.

Pedagogy of recognition understood in this manner may become a way to make our modern Polish "broken" narration united again.

\section{References}

Arendt H. (2008) Korzenie totalitaryzmu, transl. by D. Grinberg, M. Szawiel, Warszawa, Wydawnictwo Akademickie i Profesjonalne.

Bauman Z., Tester K. (2003) O pożytkach wątpliwości. Rozmowy z Zygmuntem Baumanem, Warszawa, Wydawnictwo Sic!

Bruner J. (1960) Myth and mythmaking in: Myth and mythmaking, H. Murray (ed.), New York, George Braziller. 
Bruner J. (1971) O poznawaniu, transl. by E. Krasińska, Warszawa, PIW.

Cielemęcka 0. (2014) Kto zabiega o uznanie? Moralna logika konfliktu społecznego według Axela Honnetha, "Etyka", 48: 157-163.

Gieysztor A. (1982) Mitologia Słowian, Warszawa, Wydawnictwa Artystyczne i Filmowe.

Honneth A. (2012) Walka o uznanie. Moralna gramatyka konfliktów społecznych, transl. by J. Duraj, Kraków, Zakład Wydawniczy “Nomos”.

Janion M. (2007) Niesamowita Słowiańszczyzna, Kraków, Wydawnictwo Literackie.

Kwaśnica R. (2014) Dyskurs edukacyjny po inwazji rozumu edukacyjnego. O potrzebie refleksyjności, Wrocław, Wydawnictwo Naukowe Dolnośląskiej Szkoły Wyższej.

Luckman T. (2011) Niewidzialna religia: problem religii $w$ nowoczesnym społeczeństwie, transl. by L. Bluszcz, Kraków, Zakład Wydawniczy "Nomos”.

Łowmiański, (1979) Religia Słowian i jej upadek, Warszawa, Państwowe Wydawnictwo Naukowe.

MacIntyre A. (1996) Dziedzictwo cnoty, transl. by A. Chmielewski, Warszawa, Państwowe Wydawnictwo Naukowe.

Modzelewski K. (2004) Barbarzyńska Europa, Warszawa, Iskry.

Nowak-Dziemianowicz M. (2016) Walka o uznanie w narracjach. Jednostka i wspólnota w procesie poszukiwania tożsamości, Wrocław, Wydawnictwo Naukowe Dolnośląskiej Szkoły Wyższej.

Ortega y Gasset J. (2006) Bunt mas, Warszawa, Warszawskie Wydawnictwo Literackie "Muza".

Skarga B. (2006) Inteligencja zamilkła, "Gazeta Wyborcza”, 12.

Skrok Z. (2006) Słowiańska moc, czyli o niezwykłym wkroczeniu naszych przodków na europejskq arenę, Warszawa, Iskry.

Strzelczyk J. (2002) Słowianie Połabscy, Poznań, Wydawnictwo Poznańskie.

Sucharski T. (2008), Marii Janion zmagania się z polskimi traumami, "Teksty Drugie", 6: 224-238.

Szlendak T., Olechnicki K. (2018) Nowe praktyki kulturowe Polaków, Warszawa, Państwowe Wydawnictwo Naukowe. 
Szyjewski A. (2003) Religia Słowian, Kraków, Wydawnictwo WAM.

Wasilewski J. (2012) Opowieść o Polsce. Retoryka narracji, Warszawa, Wydawnictwo Hademade.

Witkowska A. (1969) Słowiański mit poczq̨tku, "Pamiętnik Literacki: czasopismo kwartalne poświęcone historii i krytyce literatury polskiej”, 60 (2): 3-39.

\section{Online resources}

https://www.film.org.pl/prace/machulski/solidarnosc.html [accessed: 09.07.2019]. 